REMAATE DIE MUALIES

Campinas-SP, v.38 n.2, pp. 726-762, jul./dez. 2018

\title{
O INFERNO É VERDE E “AS PALAVRAS” DE LESLIE KAPLAN EM TRADUÇÃO (INÉDITA) ${ }^{1}$ PARA O PORTUGUÊS
}

\author{
José Roberto Andrade Féres ${ }^{2}$
}

\begin{abstract}
Resumo: Leslie Kaplan, nascida em Nova Iorque em 1943, mas criada desde muito cedo na França, escreve peças de teatro, romances, poemas, teoria, crítica literária e cinematográfica, tudo isso, sobretudo, em língua francesa. Poucas traduções da sua obra são encontradas no Brasil, e essa escassez de textos seus em português é, certamente, um dos motivos que me levaram a selecionar e traduzir dois de seus poemas longos (ainda inéditos na nossa língua, mas que serão publicados em breve pela editora Luna Parque): O inferno é verde [L'enfer est vert] e "As palavras (escrever, literatura e sociedade)" [Les mots (écrire, littérature et société)]. A poesia de Kaplan traz à mente questões sobre a tradução de poemas que muito se assemelham à prosa (embora seus versos livres nem
\end{abstract}

1 Minhas traduções eram inéditas no momento em que submeti este artigo, porém não o são mais, pois o livro foi publicado pouco antes de eu ter recebido o aceite da revista. No entanto, para possibilitar um confronto entre a versão final e esta que aqui se encontra, decidi manter as menções à sua "futura" publicação e (quem sabe, para alguém que, como eu, gosta de bancar o(a) geneticista, mesmo com traduções) as citações continuam da forma como estavam no momento da submissão, ou seja, tal qual antes da última e minuciosa leitura de Marília Garcia e Leonardo Gandolfi, que contribuíram imensamente para a versão final, mesmo já estando com a recém-nascida Rosa nos braços. Outras pessoas que me foram igualmente indispensáveis, agora em relação a este artigo, foram os(as) pareceristas deste periódico, que não somente apontaram algumas das falhas e lacunas das minhas reflexões, mas ainda ofereceram generosas pistas sobre como revisá-las. Aproveito então para agradecer aos(às) vários(as) "invisíveis" que tanto colaboram, sempre, com os nossos textos e que raramente são lembrados(as) - assim como, às vezes, os(as) tradutores(as) -, além de registrar aqui um grande merci a Leslie Kaplan, que muito gentilmente nos cedeu os direitos para a publicação do livro e dos trechos de sua obra neste artigo.

2 Departamento de Letras Estrangeiras modernas, Universidade Federal da Paraíba <andradeferes@yahoo.com.br>. Nome literário: Zéfere. 
sempre sejam tão livres assim) e reflexões sobre como se pode traduzir um texto escrito em mais de uma língua e que aproxime culturas aparentemente muito distantes umas das outras, pois $O$ inferno é verde, cujo ponto de partida é uma viagem da escritora a Recife, faz uso das línguas francesa, inglesa e portuguesa. Trechos da tradução são analisados em comparação com os originais e escolhas tradutórias são justificadas com o auxílio de diversos escritos que concernem ao ofício, inclusive com as próprias palavras de Leslie, que afirma que "traduzir é sexy".

Palavras-chave: Leslie Kaplan; poesia francesa; tradução.

Leslie Kaplan já escreveu peças de teatro, romances, poemas, teoria, crítica literária e cinematográfica, tudo isso sobretudo em língua francesa, e digo "sobretudo" porque, como afirma Agathe Torti-Alcayaga (2015, p. 2), ela "escreve num English-friendly French: um francês que deixa transparecer seu amor pelo inglês". ${ }^{3}$ Apesar de ter nascido em Nova Iorque, em 1943, foi aos dois anos para a França e lá foi criada, escolarizada em língua francesa, mas em convívio constante com a língua inglesa em casa. O bilinguismo, por isso, sempre toma corpo de uma forma ou de outra na sua escrita (em citações de referências anglófonas, por exemplo), bem como nos poemas que traduzi e comento aqui: $O$ inferno é verde (que constitui um livro por si só, L'enfer est vert) e "As palavras (escrever, literatura e sociedade)" (que é um dos três textos que formam o volume intitulado Les mots). O primeiro foi originalmente publicado em $2006 \mathrm{e}$ o segundo, em 2007.

São poucas, no Brasil, as traduções de que dispomos da obra da autora; não encontramos senão três: o romance $O$ psicanalista, em tradução de Rosa Freire d'Aguiar; "Amor redondo", três páginas de prosa traduzidas por Carlito Azevedo (para o número 20 da Inimigo Rumor: Revista de Poesia); e o poema "Translating is Sexy”, que Marília Garcia traduziu e publicou (com os devidos créditos a Leslie Kaplan) no seu livro Um teste de resistores. Essa escassez de versões de textos seus em português é, certamente, um dos motivos que me levaram a selecionar e traduzir dois de seus poemas longos, aqueles mencionados no parágrafo anterior, ainda inéditos na nossa língua. Essas traduções serão em breve publicadas pela editora Luna Parque, que se dedica quase que exclusivamente à poesia,

3 "[...] écrit dans un English-friendly French: un français qui laisse transparaître l'amour de l'anglais". São minhas todas as traduções de citações em línguas estrangeiras que não vierem acompanhadas pelos nomes dos(as) tradutores(as). 
seja de autores lusófonos seja de estrangeiros em traduções para a língua portuguesa.

A intenção que se tem com este artigo é a de que seja, antes de mais nada e acima de tudo, um dedo de prosa sobre poesia e tradução, e principalmente sobre a tradução de poemas prosaicos (apesar de escritos em versos, em versos livres, que nem sempre são tão livres assim), mais especificamente a dos dois de Leslie Kaplan que aqui se pretende, igualmente, apresentar e comentar. Trechos da tradução serão analisados em comparação com os originais (que se encontram reunidos lado a lado no "Anexo" deste ensaio, após as "Referências"), iniciando-se com "As palavras", que servirá como uma espécie de introdução para se chegar a O inferno é verde, texto em que, tendo sido escrito a partir de uma viagem que a autora fez a Recife, nele ela faz uso não somente do francês e do inglês, mas também do português. E o que fazer quando se traduz um texto escrito em três línguas?

As escolhas tradutórias serão justificadas com o auxílio de diversos escritos que concernem ao ofício, inclusive com as próprias palavras de Leslie, que afirma que "traduzir é sexy", "no sentido realmente literal e material de que, no fato de se traduzir, há um vai e vem, e que esse vai e vem é absolutamente sexy" (KAPLAN et al., 2015, p. 1).4

$* *$

Na sua Oficina de tradução, Rosemary Arrojo (1997, p. 32) pede que "suponhamos que o seguinte fragmento seja [...] um bilhete deixado por um hóspede [...] sobre a mesa da cozinha de seu anfitrião": "This is just to say I have eaten the plums that were in the icebox and which you were probably saving for breakfast. Forgive me, they were delicious: so sweet and so cold". 5

Em seguida, ao revelar que "o fragmento acima é, na verdade, um poema” e ao reapresentá-lo em versos, tal como o escreveu o "americano William Carlos Williams (1883-1963)”, Arrojo (1986, p. 32-34) demonstra

4 “[...] au sens vraiment littéral et matériel que dans le fait de traduire, il y a un va-et-vient, et que le va-et-vient, c'est absolument sexy”.

5 E esta é a tradução que ela nos oferece, como se fosse feita por "tradutores de um simples bilhete" e cujo intuito seria "reproduzir a informação e o pedido de desculpas": "Este bilhete é só para lhe dizer que comi as ameixas que estavam na geladeira e que provavelmente você estava guardando para o café da manhã. Desculpe-me, elas estavam deliciosas, tão doces e geladas" (ARROJO, 1986, p. 32). 
como esta informação faria com que olhássemos o texto com outros olhos, pois “ao sermos apresentados ao 'mesmo' fragmento, agora rotulado de poema, o que antes era prosaico passa a ser poético" e, muito provável e consequentemente, aquela tradução que teríamos feito do "texto/ bilhete", sem grandes reflexões prévias, não se daria da mesma maneira se já soubéssemos que se tratava de um “texto/poema”, em que buscaríamos sentidos figurados para as palavras, repetições sonoras, uma possível métrica, assim como a autora o faz mais ao fim do seu livro, onde analisa e propõe traduções de outros poemas.

A concepção de Arrojo, tanto do "poético" enquanto um ponto de vista do leitor, e não uma característica inerente ao texto, quanto de como se traduz a partir do momento em que se prega o rótulo de "poesia" num texto, muito nos interessa aqui, já que a escrita de Leslie Kaplan sempre transita entre a prosa e a poesia.

Ora, basta abrirmos o dicionário em busca dos verbetes "poético" e "poesia" para nos darmos conta de que esses termos não se referem exclusivamente ao texto escrito em versos, tampouco apenas aos textos escritos, e nem sequer somenteaos textos (uma pessoa, um fato, até mesmo uma pedra pode ser poética, ainda que não esteja no meio de um caminho drummondiano). Aliás, é justamente esse o procedimento de abertura do “Fazer, a poesia", de Jean-Luc Nancy (2013, p. 416): ele o inicia por uma consulta às definições de "poesia" contidas no Littré e afirma que "poesia é, portanto, a unidade indeterminada de um conjunto de qualidades que não estão reservadas ao tipo de composição denominado 'poesia"” e, também, que, "em seu sentido figurado, diz-se poesia de tudo o que há de elevado, de tocante, em uma obra de arte, no caráter ou na beleza de uma pessoa e até mesmo em uma produção natural" (p. 416, na tradução de Letícia Della Giacoma de França, Janaina Ravagnoni e Mauricio Mendonça Cardozo). É claro que esse não é nada mais que o pontapé inicial para que suas reflexões se desdobrem em conclusões muito mais complexas, mas, por ora, minha intenção não é me estender sobre o que é "poético", ${ }^{6}$ e sim (fazer) perceber - isto, sim, é muito importante na hora

6 É importante salientar que, apesar de Jean-Luc Nancy mencionar "qualidades" da "poesia", reflete-se hoje em dia sobre uma "poesia sem qualidades", sem características preestabelecidas e bastante prosaicas, um tanto quanto em sintonia com os escritos de Leslie Kaplan. Para quem quiser se aprofundar no assunto, um texto valiosíssimo (de cujo título tomei emprestada a expressão entre aspas na frase anterior) é o "Qualidades para uma poesia sem qualidades”, de Masé Lemos (2017), que aproxima as questões lançadas por "pós-poetas" franceses (como Jean-Marie Gleize e Christophe Hanna) com aquelas 
de refletir sobre escolhas tradutórias - que, na escrita de Leslie, a "poesia”, por mais "indeterminada" que seja, está presente tanto na sua prosa quanto nos seus versos, uma "poesia” que, para uns, pode nem mesmo ser tão "poética" assim, por ser por demais "prosaica”, já que são raros os casos em que ela se deixa confundir com o "elevado", o "tocante”, com o que há de sublime nas belas letras, na bela poesia, na poesia pura e rigorosamente versificada. Como exemplo, proponho a leitura dos trechos abaixo, ambos de Leslie, sendo que o primeiro é retirado do romance Le psychanalyste (KAPLAN, 1999, p. 128), cuja tradução de Rosa Freire d'Aguiar insiro na nota de rodapé, e o outro é parte do poema Les mots, com tradução minha no rodapé:

[...] on a l'impression qu'il danse sur les mots, avec d'autres mots derrière ou dessous [...] on a l'impression de voir le langage comme un objet, les mots sont des choses que l'on peut manipuler, accompagner avec les mains, dessiner dans l'espace, des boîtes magiques à plusieurs fonds, à plusieurs épaisseurs [...]. (KAPLAN, 2001, p. 143-144) ${ }^{7}$

e

pour moi, la littérature, c'est ça

savoir où l'on est

essayer

et le dire, et le questionner

$[\ldots]$

la démocratie exige de la pensée

concrète

c'est fatiguant

c'est réjouissant

et la littérature c'est ça: penser concrètement

levantadas pelo poeta e editor português Manuel de Freitas (de cuja antologia Poetas sem qualidades, Lemos, por sua vez, havia emprestado a expressão "poesia sem qualidades"). Em outro de seus artigos, dentro do mesmo tema (apesar de não inserir a poesia portuguesa na discussão, e sim relacionar os franceses com algo da poesia brasileira e questões "da arte minimalista americana e de seu desdobramento na Land art"), Masé Lemos (2014, p. 143) conclui com algo que também nos ajuda a pensar sobre como é penoso definir um gênero para textos como os de Leslie (ainda que esta não seja mencionada nesses ensaios): "A poesia está em processo de mudança constante a ponto de não ser muitas vezes 'reconhecível', e sua resistência se encontra exatamente nessa dificuldade" (LEMOS, 2014, pp. 147-148).

7 “[...] tem-se a impressão de que dança sobre as palavras, com outras palavras atrás ou embaixo [...] tem-se a impressão de ver a linguagem como um objeto, as palavras são coisas que podemos manipular, acompanhar com as mãos, desenhar no espaço, caixas mágicas com vários fundos, várias espessuras" (KAPLAN, 2001, pp. 143-144) (comentário de Maurice Blanchot (1987, p. 35)). 
avec des mots

qui rendent compte des détails

pas des concepts

pas des idées

des mots

pris au sérieux

pris comme interlocuteurs. ${ }^{8}$

(KAPLAN, 2007, p. 8)

Todas essas palavras a palavrear sobre essas palavras soam bastante prosaicas, poderiam inclusive nos fazer pensar numa prosa ensaística, em crítica, teoria literária ou algo semelhante. No entanto, como já foi dito, estamos lidando com romance e poesia, apesar de tampouco ser fácil distinguir um do outro, já que ambos parecem, além de muito prosaicos (seja pelos seus temas seja pela falta de uma estrutura rímica ou métrica regular), muito poéticos ao mesmo tempo (pela presença, por exemplo, de repetições sonoras, técnica que podemos associar a uma poesia mais tradicional). Para reforçarmos um dos motivos que fazem com que não seja tão simples delimitar as fronteiras entre os gêneros textuais em questão, podemos até retornar a tempos mais remotos e retomar o que declara Roman Jakobson (2007, p. 127) sobre a "função poética" da comunicação verbal, que não se restringe à poesia, assim como a poesia não se limita somente à "função poética": "Qualquer tentativa de reduzir a esfera da função poética à poesia ou de confinar a poesia à função poética seria uma simplificação excessiva e enganadora”.

Assim sendo, arrisco conjeturar que o primeiro excerto literário que citei, parte de um romance de Leslie Kaplan, e não de um poema, pode ser considerado por grande parte de leitores(as), talvez por causa do seu tom mais "elevado" e "tocante", doce e suave (com a imagem da dança, do desenho, da caixa mágica...), mais "poético" que o segundo. Ademais, no caso dos textos de Leslie, nem mesmo se eu tivesse optado por citar um trecho narrativo teria sido fácil diferenciar o romance do poema, pois a narrativa também está presente em ambos; n'O inferno é verde, existem até mesmo diálogos, algo que não se costuma encontrar em "poesia” (em

8 “[...] para mim, a literatura é isso/ saber onde a gente está/ tentar / dizer, questionar [...] a democracia exige pensamento/ concreto/ cansa a gente/ anima a gente/ e a literatura é isso: pensar concretamente/ com palavras/ que deem conta dos detalhes/ não dos conceitos/ não das ideias/ das palavras/ tomadas a sério/ tomadas como interlocutores". 
trechos que, por falta de espaço suficiente, não cito no "Anexo" deste artigo, infelizmente).

Está claro, portanto, que as fronteiras entre os gêneros não são tão nítidas, e muito menos quando lidamos com textos como os de Leslie, cujo primeiro livro, L'excès-l'usine [O excesso-a fábrica], rendeu o seguinte comentário de Maurice Blanchot 1987, p. 35): “Talvez seja poesia, talvez seja mais do que poesia", 9 enquanto que Jean-Marie Gleize (2010, p. 127) considera a "prosa" desse mesmo livro de Kaplan um "modelo" para a "simplificação, a neutralização, a literalização", "uma prosa excessivamente [...] simples, plana, mínima”, que ele mesmo tenta alcançar na sua "pós-poesia". ${ }^{10}$ Isso significa dizer, igualmente, que, às vezes, se um mesmo texto da autora pode ser definido como "poesia” por uns e "prosa” por outros, ${ }^{11}$ a maneira pela qual se traduz um "poema" também pode não ser tão diferente da forma como se faz a tradução de um romance ou de qualquer outro de seus escritos. Como atesta Paulo Rónai (2012, p. 80) a respeito da "tradução literária e a tradução técnica", "enganar-se-ia quem as julgasse dois domínios opostos ou mesmo separados”.

Vejamos então um exemplo de uma questão que pode ser considerada bastante prosaica e que me veio no processo tradutório d'“As palavras" de Kaplan, poema que sugeri muito se assemelhar também a um ensaio, conquanto tenha sido escrito em versos. A questão levantada concerne à tradução das frases interrogativas francesas, que, enquanto na linguagem falada podem ser expressadas por uma simples alteração na entonação de afirmativas, já na escrita formal, aparecem marcadas pela fórmula "est-ce que" ou pela inversão do sujeito em relação ao verbo (por exemplo: "est-elle" em vez de "elle est"). Ou seja, bem como

9 “C'est peut-être de la poésie, c'est peut-être plus que la poésie". Essa frase foi retirada de um excerto de resenha de Maurice Blanchot (originalmente publicada no Libération, em 24/2/1987), presente na ficha do livro L'excès-l'usine e publicada no site da editora POL: (disponível em: <http://www.pol-editeur.com/index.php?spec=livre\&IS $\mathrm{BN}=2-86744-078-5>)$.

10 "Un modèle"; "la simplification, la neutralisation, le littéralisation"; "Une prose excessivement [...] simple, plate, minimale".

11 Leslie Kaplan diz numa entrevista de 2013 (disponível em: https://www.youtube.com/ watch?v=Mqd3fPobr7g) que, caso precisasse classificar L'excès-l'usine, ela não usaria os termos "roman ou poésie" [romance ou poesia], mas "réel" [real], palavra bastante cara a Gleize também (e que não deve ser confundida com um "realismo" naturalista à Émile Zola). Digo isso, no entanto, não no intento de encontrar o melhor rótulo para a obra de Leslie, mas para, quiçá, contribuir com uma pista a quem o queira fazer; afinal de contas, meu foco é refletir sobre a tradução de seus textos, e não os rotular. 
no inglês (em que a pergunta também se faz com a colocação do sujeito após o verbo, o auxiliar, no caso) ou no espanhol (em que o ponto de interrogação invertido " $i$ ” evidencia a pergunta antes mesmo de ela ser colocada), na língua francesa escrita sabemos se a sentença é interrogativa desde o início; no português, não. E isso diz respeito a uma questão que se apresenta à tradução de qualquer gênero textual. Para vermos um caso concreto, peguemos um dos textos de Jakobson traduzidos para o francês por Nicolas Ruwet e, para o português, por Izidoro Blikstein e José Paulo Paes, "Aspectos linguísticos da tradução", que será útil também para nossa argumentação.

Em inglês, na língua em que o ensaio foi originalmente escrito, encontramos logo na primeira página uma pergunta introduzida peloverbo to do, que, enquanto auxiliar, permite que saibamos, imediatamente, que há ali uma pergunta: “does a word simply name [...]?” (JAKOBSON, 1959, p. 232). Traduzida em francês, também sabemos desde o início que a frase é interrogativa, graças à inversão do sujeito "désigne-t-il" (com o pronome/ sujeito "il" após o verbo "désigne"): "le mot désigne-t-il simplement [...]?" (JAKOBSON, 2003, p. 78). Trata-se, em ambas as línguas, de procedimentos meramente funcionais, desprovidos de qualquer carga semântica (embora uma inversão do sujeito no francês soe mais formal que o uso de um "estce que”). Porém, em português, para que, já à primeira vista, fique claro que a frase é interrogativa, uma vez que não possuímos a mesma estrutura sintática das línguas inglesa ou francesa, nossos tradutores optam por: “será que a palavra designa simplesmente [...]?” (JAKOBSON, 2007, p. 64, grifos meus nas três citações).

Se na prosa teórica de Jakobson, em que o ponto de interrogação ao fim da frase já não deixa dúvidas de que se trata de uma pergunta, e, mesmo assim, os tradutores ainda resolveram acrescentar "será que", imagine como essa estratégia pode vir a calhar (e veio!) quando o ponto de interrogação é omitido, algo que ocorre com bastante frequência em Leslie Kaplan.

Nas primeiras perguntas que a escritora insere n'“As palavras" (e em algumas outras sentenças interrogativas, poucas, mais ao fim do poema), os pontos de interrogação estão de fato lá (ver o "Anexo" deste artigo); no entanto, na maioria das demais, as únicas marcas interrogativas presentes são o "est-ce que" ou a inversão do sujeito, estruturas que, apesar de não existirem no português, não são intraduzíveis; - para recordar Jakobson (2007, p. 69) novamente: "as línguas diferem essencialmente naquilo 
que devem expressar, e não naquilo que podem expressar". Lanço mão, portanto, de técnicas semelhantes à de Izidoro Blikstein e José Paulo Paes na minha tradução, às vezes para reforçar a interrogação (onde há pontuação, como no exemplo [1] abaixo), às vezes para evidenciar que se trata de uma pergunta (quando o ponto de interrogação não é usado, como nos exemplos [2], [3] e [4] a seguir) (grifos meus):

\begin{tabular}{|l|l|}
\hline $\begin{array}{l}\text { [1] pour moi la littérature est un } \\
\text { questionnement } \\
\text { est-ce que c'est un questionnement direct? }\end{array}$ & $\begin{array}{l}{[1] \text { para mim a literatura é um questionamento }} \\
\text { será que é um questionamento direto? }\end{array}$ \\
$\begin{array}{l}\text { [2] si je vis telle situation, si je l'éprouve, } \\
\text { qu'est-ce que ça veut dire, } \\
\text { qu'est-ce que je peux en dire }\end{array}$ & $\begin{array}{l}{[2] \text { se eu vivo algo, se eu passo por tal situação, }} \\
\text { o que é que isso quer dizer, } \\
\text { o que é que eu posso dizer disso }\end{array}$ \\
$\begin{array}{l}\text { [3] c'est-à-dire: comment je veux vivre, } \\
\text { ici et maintenant } \\
\text { moi } \\
\text { vous }\end{array}$ & $\begin{array}{l}{[3] \text { ou seja: como é que eu quero viver, }} \\
\text { aqui e agora } \\
\text { eu } \\
\text { você }\end{array}$ \\
$\begin{array}{l}\text { [4] est-ce qu'une réponse autoritaire } \\
\text { est un signe d'autorité } \\
\text { ou au contraire de manque d'autorité } \\
\text { réelle } \\
\text { d'autorité porteuse de sens } \\
\text { la littérature est une façon de penser }\end{array}$ & $\begin{array}{l}\text { [4] uma resposta autoritária } \\
\text { seria ela um sinal de autoridade } \\
\text { ou, pelo contrário, de falta de autoridade } \\
\text { real } \\
\text { de autoridade portadora de sentido } \\
\text { a literatura é uma forma de pensar }\end{array}$ \\
\hline
\end{tabular}

Em [1], sem o acréscimo de "será que" na tradução, o ponto de interrogação poderia se referir a ambos os versos, sendo que, em língua francesa, o "est-ce que", presente no segundo verso, deixa claro que a pergunta só começa ali. É para evitar o surgimento de dúvidas como essa que faço surgirem tais estruturas ao traduzir, estruturas que se fazem ainda mais necessárias em [2], [3] ou [4], em que a pontuação interrogativa é omitida.

No segundo caso, [2], “o que é que” não chega a ser indispensável, mas no terceiro, [3], se a tradução proposta fosse "como eu quero viver,/ aqui e agora/ eu/ você”, o trecho poderia ser lido, devido à falta de pontuação, como uma exclamação, ambiguidade que não é gerada em francês, língua em que há uma diferença óbvia entre "comment", palavra interrogativa, e "comme", que é comparativo e exclamativo. Na língua portuguesa, contamos apenas com "como", para todas essas funções; por isso ele se 
torna ambíguo, se não vier acompanhado de algo mais; por esse motivo, traduzo o "comment" por "como é que".

Quanto ao exemplo [4], ainda me pergunto se, para um(a) brasileiro(a), basta a inversão do sujeito ("seria ela") para evidenciar que há uma pergunta ali, ou se essa inversão pode ser interpretada como uma mera nuance mais formal da escrita. De qualquer maneira, havendo no verso seguinte a oposição "ou, pelo contrário", o questionamento se avulta, com ou sem ponto de interrogação, ponto que se faz desnecessário graças também à disposição do texto em versos, graças aos saltos de linha, que fazem as vezes, às vezes, da pontuação omitida. Caso não houvesse nem a interrogação nem o salto de linha no último exemplo, entre "de autoridade portadora de sentido" e "a literatura é uma forma de pensar", já que tampouco existem maiúsculas nos inícios de frase em Leslie, a compreensão e, por conseguinte, a tarefa do tradutor seriam ainda mais árduas.

Vê-se aqui igualmente que, por mais prosaica que seja, a poesia da autora transgride as normas gramaticais da prosa mais corrente, eliminando pontuação, maiúsculas etc. Só que tampouco segue à risca regras formais de uma poesia mais tradicional, como métrica e rima, o que não quer dizer que as ignora ou abandona por completo nos seus versos livres. Como recorda Paulo Henriques Britto (2012, p. 146), segundo “o poeta anglo-americano T. S. Eliot, quando o poeta sabe o que está fazendo, o verso nunca é realmente livre”; escrever em versos livres não quer necessariamente dizer que tudo será aleatório e desregrado; traduzir versos livres tampouco significa abandonar ao acaso o rigor do(s) texto(s).

Eu me lembro de um poema (dois, na verdade...) de Marcus Vinicius de Freitas (2005, p. 109), por Marcus Bacamarte, seu pseudônimo nos primeiros livros de poesia. Começa assim:

Na beira do rio

Providence

vejo passarem os anos;

e apesar do common sense de rimar

águas e enganos

o rio lá

corre sempre. 
Na verdade, não começa assim, começa com uma epígrafe retirada de Fernando Pessoa: "Na ribeira deste rio/ ou na ribeira daquele/ passam meus dias a fio", versos cujos "rio" e "fio" ecoam e rimam com o primeiro verso de Freitas. Por aí já vemos que o salto de linha de Freitas, após a palavra “rio", não é à toa; seus versos não são tão livres assim, estão atados, pela rima, aos de Pessoa. E Freitas também tem suas rimas próprias, cujas definições retomo de Norma Goldstein (2002, pp. 44-45): as externas, de fim de verso (como a consoante anos/enganos, em que tanto as consoantes quanto as vogais rimam, e as toantes Providence/sempre e rimar/lá, em que a rima se dá pela vogal tônica tão-somente) e as internas, dentro dos versos (como Providence/sense/sempre ou rimar/águas/lá).

Mas tudo fica bem mais interessante quando se percebe que algumas dessas rimas externas já foram um dia internas e vice-versa, pois, no mesmo livro, No verso dessa canoa (volume em que se reúnem quatro dos seus livros anteriores), mais de noventa páginas antes (FREITAS, 2005, p. 17), havia uma outra versão do mesmo poema, que se diferencia pela disposição das palavras na folha:

\footnotetext{
Na beira do rio Providence

vejo passarem os anos;

e apesar do common sense

de rimar águas e enganos

o rio lá corre sempre.
}

Enquanto, nos versos livres, a rima com Pessoa é externa e se dá pelo "rio" deixado no fim do primeiro verso de Freitas, aqui a rima do "rio" é interna, e o que ecoa de Pessoa são as redondilhas maiores (os versos, todos, de sete sílabas) ${ }^{12}$ e o esquema rímico ABABA, além do tema revisitado.

Outro ponto curioso de se notar é que, nesses versos livres, o fato de se agrupar o terceiro verso com parte do quarto da versão metrificada (assim: "e apesar do common sense de rimar"), a ênfase é dada no verbo "rimar", que passa a ocupar a posição final do verso. Além de servir, no livro, de pista para quem não se lembrar, mais de noventa páginas depois, que já havia lido essas palavras, só que em outro tipo de arranjo, isso serve também, para nós, como uma evidência a mais de que o verso livre nem sempre é tão livre assim, que podem figurar, nele também, algum tipo de

\footnotetext{
12 Para quem quiser conferir a regularidade da métrica de Freitas, sugiro um exercício de letrista/compositor: coloque para tocar a música que Dori Caymmi fez com o poema de Pessoa e tente cantar os versos de Marcus Vinicius dentro da mesma melodia; vestem como uma luva.
} 
métrica (por mais mínima que seja, e/ou até mesmo involuntária), além de rimas internas e externas, tal qual constataremos em Leslie Kaplan.

"As palavras" de Leslie, portanto, embora bastante prosaicas e em versos livres, não deixam de apresentar, aqui e ali, algumas rimas e até uma certa regularidade métrica vez ou outra, que não podem ser negligenciadas na tradução, como aqui:

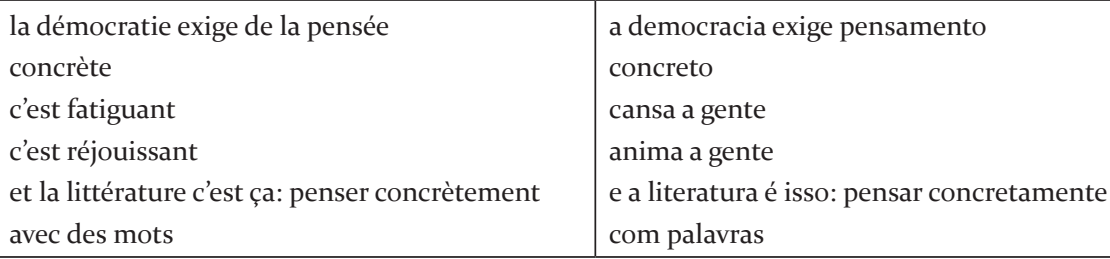

Acima, a regularidade dos versos 3, 4 e 6 é inquestionável, todos com quatro sílabas poéticas (apesar de podermos contar cinco em "c'est réjouissant", se considerarmos como um hiato esse "oui" que grifei). Essa regularidade é reproduzida na tradução, só que com versos de três sílabas poéticas (se unirmos na leitura em voz alta, graças ao enjambement, o $e$ átono da "gente" do terceiro verso com o a átono do "anima" do quarto verso), ou quatro sílabas, no caso de "anima a gente", que se encontra na mesma posição do impreciso número de sílabas de "c'est réjouissant".

Também não há dúvida de que, já que as nasais francesas "an" e "en" se pronunciam da mesma forma, "fatiguant", "réjouissant" e "concrètement" formam uma rima externa, rima que transcrio (tentando entrar em sintonia com transcriações haroldianas) trazendo uma nova estrutura sintática para os versos. Uma tradução mais literal de "c'est fatiguant/ c'est réjouissant" seria algo como "é cansativo [ou desgastante ou estafante...]/ é regozijador [ou prazeroso ou animador...]", que não rimaria com o "concretamente" do verso seguinte. Então prefiro transformar a estrutura frasal, colocando "cansa a gente/ anima a gente", produzindo, assim, uma nova rima para "concretamente".

Agora, trazendo à tona a alusão que Jakobson (2007, p. 142) faz a palavras de Wimsatt e Beardsley, dizendo que "há muitas recitações possíveis de um mesmo poema - que diferem entre si de muitas maneiras", mas sem sair da análise do último trecho de Leslie, há ali algo que sempre me espanta nos versos franceses, mesmo em alguns que são (aparentemente) livres: o alexandrino parece se fazer quase que onipresente neles, de uma forma ou de outra. Se rearranjarmos os versos 
que ainda não comentei (mais ou menos como Freitas reorganizou os seus, comentados mais atrás) e os recitarmos com uma pronúncia mais informal, corrente, como no ritmo do cotidiano (bastante condizente com a escrita tão prosaica de Leslie), sem dar voz aos ee mudos, por exemplo, em vez de treze ou quatorze sílabas (resultado da contagem formal que acabo reproduzindo na tradução), encontraríamos dois versos de doze sílabas ali, dois alexandrinos (embora não tão rigorosos, desprovidos da cesura, da tônica na sexta sílaba), que eu escandiria assim:

la/ dé/mo/cra/tie/ e/xige/ d' la/ pen/sée/ con/crète

et/ la/ li/tté/ra/ture/ c' ça:/ pen/ser/ con/crèt'/ment

O mais intrigante é que, até mesmo no slam (que não é um gênero poético a parte, mas uma espécie de spoken word que bebe diretamente da fonte do rap e do hip-hop), feito num registro geralmente mais popular, oral, grande parte das vezes manifestando alguma sorte de protesto e denúncia social (mas não somente) a partir de experiências de vida muito pessoais, até mesmo no slam o alexandrino acaba dando as caras, de uma maneira ou de outra. Por exemplo, vejamos os dois primeiros versos de "Les voyages en train", texto (e também faixa do álbum Midi 20) de Grand Corps Malade, um dos mais famosos poetas/slammeurs da França:

J'crois que les histoires d'amour c'est comme les voyages en [train,

Et quand je vois tous ces voyageurs parfois j'aimerais en être [un.

Na escrita, esses versos são irregulares e contêm mais de doze sílabas cada. Entretanto, quando oralizados (com a pronúncia que tento transcrever abaixo, como fiz logo acima com os versos de Leslie), não é que chegamos a alexandrinos, e, ainda por cima, com cesura na sexta sílaba (que marco a seguir com os saltos de linha)?!...:

J' crois/ qu' les/ his/toires/ d'a/mour

[c' comme/ les/ voy/ages/ en/ train,

't quand/ j' vois/ tous/ c' voy/a/geurs

[par/fois/ j'ai/m'rais/'n ê/tre un.

Mesmo não se tratando de Racine ou Corneille, alguns pares de versos franceses atuais, advindos da cultura popular e oral, como os de Grand Corps Malade, podem lembrar bastante os dísticos da literatura clássica; sons do século XVII ainda ressoam no XXI. Félix Jousserand (2009, p. 182), 
escritor, artista, não só da cena slam e do rap, mas também do teatro, diz o seguinte, numa entrevista sua:

Quando escrevo, falo [em voz alta] o texto para sentir o ritmo. Na passagem para o oral, é tão surpreendente encontrar elementos de uma métrica bastante clássica no interior de um texto que não é nada clássico. $\mathrm{O}$ alexandrino vem à tona. Como que por acaso [...] quando o som sai legal, pois é, é isso mesmo, são doze sílabas com uma cesura no meio, enquanto que, no papel, nem dá para ver. ${ }^{13}$

De volta a Leslie e sua sonoridade, vimos que esses alexandrinos "invisíveis", mas legíveis em voz alta, podem se esconder na sua escrita (e veremos outro exemplo mais adiante), mesmo nesses seus versos "livres" e tão afeitos à prosa, o que não é de se espantar. Para Pierre Alferi (2013, p. 425, na tradução de Masé Lemos e Paula Glenadel), o "ritmo, temos o costume de medi-lo por meio das formas evidentes que ele assume nos versos regulares" (grifo meu, e creio que os exemplos precedentes evidenciaram essa inevidência); no entanto, e além do mais, também "a prosa tem o seu [ritmo], mas, dizia Cícero, nada fácil de ser reconhecido” (p. 425). A propósito, ainda segundo Alferi, "a prosa não é um gênero nem o oposto da poesia. Ela é o ideal baixo da literatura, [...] um horizonte, e lhe sopra um ritmo, uma política" (p. 425). No caso de Leslie, diante da sua "prosa” ou "poesia" (se lembrarmos do seu L'excès-l'usine, que é "mais que poesia” para Blanchot, mas um "modelo" de "prosa” para Gleize...), é preciso manter o ouvido atento aos seus ritmos na hora de traduzi-la.

Ademais, poratuais que sejam os escritos de Leslie, também apresentam outros formalismos tão antigos quanto os de um alexandrino, que devem ser considerados na hora da tradução. Na segunda estrofe d'O inferno é verde, por exemplo, lê-se uma aliteração, uma consoante reiterada que penei para traduzir: o líquido encontro das palavras "bloc", "bleu" e "ciel" - "bloco", "azul” e "céu", se traduzidas literalmente. No entanto, a tradução literal em português não contém o trio de $l$ que ecoa no francês. Para promover uma repetição sonora também ao traduzir, segui as dicas de Haroldo de Campos (2006, p. 35), para o qual "não se traduz apenas o significado, traduz-se o próprio signo, ou seja, sua fisicalidade, sua materialidade mesma [...]. O

13 "En l'écrivant, je dis le texte pour sentir son rythme. Au passage à l'oral on est très surpris de retrouver des éléments de métrique très classiques à l'intérieur d'un texte qui ne l'est pas du tout. L'alexandrin remonte à la surface. Comme par hasard [...] quand ça claque bien, eh bien oui, c'est du douze avec une césure au milieu, alors que sur le papier on ne le voit pas." 
significado, o parâmetro semântico, será apenas e tão-somente a baliza demarcatória do lugar da empresa recriadora”. Portanto, assim como Campos (2006, p. 45), que, no exemplo da sua lida tradutória com um dos versos de Maiakóvski, "sem fugir do âmbito semântico”, prefere “'traduzir' a aliteração, antes que o sentido", prefiro igualmente privilegiar a sonoridade, ainda que me distancie um pouco do significado:

\begin{tabular}{|l|l|}
\hline $\begin{array}{l}\text { comme le bloc bleu } \\
\text { du ciel }\end{array}$ & $\begin{array}{l}\text { como o azul maciço } \\
\text { do céu }\end{array}$ \\
\hline
\end{tabular}

Conquanto não possa repetir no português a consoante líquida presente no "bloc bleu du ciel" francês, insiro um sibilante "maciço" no "céu”, também uma tripla aliteração, mesmo que diversa. Afinal de contas, como costumo dizer, a relação que a tradução mantém com o texto que se traduz é muito mais próxima de uma conversa do que de uma conserva. Traduções não são picles. Aliás, até mesmo picles deixam de ser pepinos a partir do momento em que estes são conservados (não é à toa que mudam de nome...), passam a ser pepinos em conserva, pois a receita leva vinagre ou outros conservantes; sem contar que picles, pepinos em conserva, jamais restarão intactos simplesmente pelo fato de estarem conservados, hão de se transformar e mudar de sabor à medida que forem curtindo e o tempo for passando, à medida que o próprio conservante for agindo e reagindo e sendo absorvido cada vez mais. Enfim, se nem uma conserva é capaz de conservar a coisa tal qual ela era antes de conservada (e tampouco depois...), por que cargas d'água a tradução deveria tentar fazê-lo?

E, já que tocamos na culinária, vejamos o tratamento que foi dado a especificidades da cultura estrangeira (e também da cultura brasileira) n'O inferno é verde.

\section{$* * * *$}

O ponto de partida d'O inferno é verde é a primeira vinda da poeta a Recife, onde lê em português, num grafite, como ela mesma menciona na primeira estrofe, as palavras que viriam a se tornar o título do seu texto: L'enfer est vert. A partir dali, ou melhor, daqui, do Brasil, os versos nos levam aos Estados Unidos (onde ela nasceu), à França (para onde foi ainda criança) e a referências de várias nacionalidades e épocas diferentes. $\mathrm{O}$ poema busca aproximar mundos aparentemente muito distantes; para usar dois dos seus versos, num linguajar bastante informal, "il y a pas mal 
de monde là-dedans/ il y a vraiment du monde" [isso inclui um mundo de gente/ realmente um mundaréu].

Ao transitar por esses diferentes mundos, assim como o texto transita entre o prosaico e o poético, claro que nos deparamos com particularidades de cada um desses mundos, mas sempre correlacionadas de alguma maneira, coabitando este único e mesmo espaço que é o do poema. $O$ inferno é verde é uma área de convívio para os paradoxos (a começar pelo título), em que tanto as diferenças quanto as semelhanças se interrogam, interagem, criam laços e se transformam em contato umas com as outras. E a tradução não poderia se realizar de outra forma.

São inúmeras as teorias e reflexões tradutórias que assumem posturas tão radicais, normativas, impositivas e intransigentes, que quase se tem a impressão de que o objetivo da tradução é o de conquistar mundos, ou dominá-los, ou separá-los, e não o de aproximá-los uns dos outros, de fazer com que convivam (bem ou mal...) uns com os outros, como parece ser o desejo do texto de Kaplan. Conforme Michaël Oustinoff (2011, p. 66), "as dicotomias tradicionais que opõem letra e espírito, forma e conteúdo, estilo e sentido, original e tradução, autor e tradução etc., remetem, na realidade, a uma visão dualista. A forma não vem se sobrepor ao sentido: os dois são indissociáveis". Não há motivo para crer que, ao traduzir, teremos que fazer ou isto ou aquilo, ou oito ou oitenta, e ponto final, embora, obviamente, sempre tenhamos que fazer escolhas que às vezes pendem mais para um lado que para o outro.

Quando lemos ensaios que se mostram armados até os dentes, munidos de um palavreado categórico e irredutível para caracterizar o autor e o original sempre em oposição ao tradutor e seu trabalho, ou dois modos únicos e inconciliáveis de traduzir, tem-se a impressão de que a tradução nunca foi feita para promover encontros, para levar universos diversos ao encontro uns dos outros, e sim para eles irem de encontro uns com os outros, uns contra os outros.

Como se lê na epígrafe da Escola de tradutores de Paulo Rónai (2012), emprestada de Guimarães Rosa, "traduzir é conviver"; e, com certeza, conviver não é fácil. Não conheço encontro algum em que apenas uma das pessoas envolvidas tenha se esforçado para manter a relação, e isso tenha dado certo, tenha feito com que o convívio se estabelecesse de maneira satisfatória (ao menos) e fosse proveitoso para todos(as). Por que, então, isso haveria de funcionar de outra forma quando se trata do encontro de línguas, de tempos, de espaços, de culturas diferentes numa tradução? 
Dificilmente encontraremos (e faremos) algo que seja tão preto no branco quanto deixam transparecer algumas teorias tradutórias; um inferno pode, sim, ser verde, por mais improvável ou paradoxal que pareça uma associação do inferno à cor verde; como escreve Leslie no seu Inferno:

\begin{tabular}{|l|l|}
\hline$[\ldots]$ ce qui empêche de voir & {$[\ldots]$ o que impede de ver } \\
le caractère double des choses & o caráter dúbio das coisas \\
c'est la haine & é o ódio \\
monotone & monótono \\
monocorde & monocórdio \\
c'est elle qui empêche de voir & é ele que impede de ver \\
\hline
\end{tabular}

Portanto, ao tentar (re-)aproximar os diferentes (e aparentemente incompatíveis) mundos aproximados por Leslie Kaplan, tanto ela quanto o(a) leitor(a) da tradução devem se mover, ninguém pode ficar estatelado na poltrona esperando que o(a) outro(a) venha, todo mundo tem que se mexer para que o encontro aconteça. Mas nunca é demais ressaltar que, em alguns momentos, uma pessoa acaba se empenhando um pouco mais que a outra, e que isso não impede que a situação se inverta em outro instante, com um empurrãozinho maior por parte de quem havia investido um pouco menos na relação minutos atrás.

Para vermos na prática como isso ocorre, eis um trecho d'O inferno é verde:

\begin{tabular}{|l|l|}
\hline$[\ldots]$ sur l'avenue de Paris & {$[\ldots]$ na avenida de Paris } \\
aux Lilas & em Les Lilas \\
il y a un Délices de Chine & tem um restaurante Délices de Chine \\
un marchand de journaux & uma banca de revistas \\
papeterie, journaux & papelaria, jornais \\
plusieurs boulangeries & várias padarias \\
(pas terribles) & (nada demais) \\
un Monoprix & um supermercado Monoprix \\
un magasin de blanc & uma loja de cama, mesa e banho \\
un, deux, trois bureaux de tabac & um, dois, três pontos de venda de cigarros \\
tout ça à la sortie du métro & tudo isso na saída do metrô \\
et aussi une rôtisserie & e também tem carne assada \\
(odeurs, grillé) & (cheiros, grelha) \\
un marchand de légumes, des halles & um verdureiro, barracas de feira \\
une lingerie & lingerie \\
des jouets & brinquedos \\
\hline
\end{tabular}


Em versos como aqueles em que aparecem Délices de Chine e Monoprix, às vezes mantenho as marcas do estrangeiro, que uma grande parcela dos(as) leitores(as) brasileiros(as) desconhecerão, mas, com o intuito de trabalhar com um meio-termo, acrescento um esclarecimento ("restaurante" e "supermercado"), sobretudo quando não consigo constatar uma preocupação métrica naquele ponto do texto, já que acréscimos como esses poderiam, sim, comprometer o ritmo de uma parte em que os versos livres dão lugar a versos metrificados (como comentei anteriormente).

Por outro lado, há momentos em que facilito um pouco mais a vida do(a) leitor(a) do que a da autora, convidando (compulsoriamente, confesso...) a última a se adaptar ao novo mundo que irá recebê-la, ou, para usar a terminologia de Lawrence Venuti (1995, p. 20), domestico o texto, trago-o mais para perto do que é familiar para o(a) leitor(a) da tradução, como ao traduzir "rôtisserie" por "carne assada". Caso eu optasse por "rotisseria”, palavra que já encontramos nestas bandas de cá, eu estaria usando um estrangeirismo que, na verdade, não teria deixado a autora tão imóvel quanto se pode imaginar, pois "rotisseria", apesar de, materialmente, ser o termo mais próximo de "rôtisserie", soa muito mais chique e elitista aqui do que na França, em que é mais comum. O mesmo tipo de transformação semântica decorrente de uma tradução literal ocorreria com o termo "grillé", caso eu elegesse como equivalente mais exato um "grelhado", já que em português pareceria bastante pomposo e, consequentemente, inverossímil (um "grelhado" numa rua do subúrbio parisiense?...), ou reforçaria a imagem estereotipada de uma Paris romântica onde tudo é lindo e limpo e magnífico, uma visão oposta da que $O$ inferno de Leslie parece tentar passar. No entanto, escolher um "espetinho", um "churrasco" ou uma "churrasqueira”, em vez de "grelha” e "carne assada", seria domesticar demais, seria como inserir uma caricatura de um dos nossos gaúchos bem no meio de um bairro periférico de Paris, vendendo suas especialidades latino-americanas para os franceses. Está certo que eu disse que Leslie tenta aproximar realidades bastante diversas na sua escrita, mas nem tanto...

Noutras horas, tomo a direção oposta (afinal de contas, como diz o ditado, "os opostos se atraem"): peço ao(à) leitor(a) que se adapte ao ambiente da autora, não acrescentando explicações nem domesticando, optando por um texto mais estrangeirizador (ainda na terminologia de Venuti), como ao me calar a respeito de "Les Lilas". Mesmo assim, só me calo aqui, pois já se mencionava Paris no verso precedente, e eu tampouco 
pretendo oferecer tudo de bandeja e de uma só vez ao(à) leitor(a); mais à frente, algumas estrofes depois, "Les Lilas" ressurge e, aí sim (assim como n'“As palavras”, que deverá vir após $O$ inferno na edição brasileira), auxilio quem não sabia do que se tratava (e/ou não foi pesquisar na ocorrência anterior), adicionando: "subúrbio de Paris".

No último excerto citado, outro momento em que não toco em nada e deixo que o(a) leitor(a) se vire é ao manter lingerie, palavra que, embora a tenhamos integrado ao nosso idioma, para ela não tomamos emprestados todos os significados que possui na língua francesa. Como empréstimo, para nós, quer dizer somente roupa íntima feminina, enquanto que, em francês, pode significar roupas íntimas em geral, ateliê de costura (de tais vestimentas), loja de roupas íntimas etc. E, obviamente, por Leslie ter escrito "une [uma] lingerie" entre todos esses estabelecimentos e produtos à venda logo na saída do metrô, não se trata de uma única peça de lingerie ali, e sim de um lugar onde se vende ou produz lingerie. Mas prefiro fazer como com a "carne assada", colocar simplesmente o produto na tradução, "lingerie", não o estabelecimento; sem contar que, em itálico, tento enfatizar que a palavra é estrangeira, que ela não nos pertence desde sempre, apontando para o que há de babélico n'O inferno é verde. A aproximação de mundos diversos no poema de Kaplan não se concretiza apenas no conteúdo, no tema, mas também na forma, na aproximação de diferentes línguas. Retornando às palavras de Oustinoff (2011, p. 66) citadas mais acima, "a forma não vem se sobrepor ao sentido: os dois são indissociáveis”, algo que busco ter em mente ao traduzir.

$* * * * *$

O inferno é verde, como já mencionei, começa com o episódio da vinda da autora a Recife, onde ela vê essa frase num grafite, frase que cita em português e, logo depois, traduz em francês: "L'enfer est vert". Outras frases e expressões aparecerão em língua portuguesa ao longo dos seus versos, todas elas traduzidas em seguida, no corpo do texto. A autora faz praticamente o mesmo com trechos que cita em inglês, mas nem sempre; às vezes não os traduz para o francês. E o que tento fazer na tradução é gerar, também, um certo "efeito babélico", ${ }^{14}$ com os mesmos procedimentos de Leslie Kaplan, às vezes traduzindo o que há de estrangeiro para nós e

14 Tomo o termo emprestado de Umberto Eco (2006, p. 147). 
outras vezes, não, mas não necessariamente nos mesmos momentos que ela.

Aqui no Brasil, o que se faz geralmente em tradução quando, num texto estrangeiro, utiliza-se algum termo da língua portuguesa, é colocá-lo em itálico e inserir uma nota de rodapé explicando que aquilo já se encontrava em português no original. O resultado, a tradução, será um texto monolíngue, inteiramente escrito em português. No entanto, no processo tradutório dos poemas de Leslie Kaplan, principalmente durante a lida com $O$ inferno é verde, onde (repito:) a aproximação de universos diversos se realiza tanto no conteúdo quanto na forma, com a aproximação de três línguas diferentes (francês, inglês e português), não cabe monolinguismo é que traduzir muito, traduzir tudo, é fácil, difícil é saber o que não traduzir.

Como meu objetivo era oferecer ao(à) lusófono(a) uma experiência trilíngue, mais ou menos como o que o texto de Leslie proporciona ao(à) francófono(a), não traduzo tudo aquilo que foi escrito em francês, língua que predomina em Kaplan; opto por deixar em língua francesa na tradução, em itálico, ora as palavras, expressões e frases que evidenciam as semelhanças entre o português e o francês (a ponto de serem compreensíveis mesmo para quem não estuda o idioma), ora as que apontam para suas diferenças, como aquelas contidas na aparentemente inócua lingerie (analisada uns parágrafos acima).

Um caso muito semelhante ao de lingerie se encontra nos versos (a seguir) em que mantenho "un garçon" na tradução, com o artigo em francês mesmo, "un", bastante inteligível para um(a) lusófono(a). Embora tenhamos integrado o substantivo ao nosso vocabulário, garçon, em francês, não diz respeito somente a quem serve mesas em restaurantes e bares (que também pode ser serveur, muito mais comum hoje em dia), mas se refere também a um jovem, criança ou rapaz qualquer. $\mathrm{O}$ que mais me interessa, no entanto, é deixar claro, com o uso do itálico, que há uma relação entre o inglês e o português ali, em vez de traduzir um único dentre os vários significados da palavra francesa.

Na mesma estrofe (a seguir), traduzo "frigidaire", não por refrigerador ou geladeira ou congelador, mas por freezer, em itálico (que utilizo também nos termos de língua inglesa que já se encontravam em Leslie), com o intuito de lançar uma luz sobre as relações do português, agora, com o inglês, potencializando relações que se manifestavam principalmente no plano temático, somente em língua francesa nesse momento do original, 
sinalizando que aquilo poderia estar acontecendo em Pequim, em "New Iorque” (com cuja ortografia brinco, multinacionalizando-a), em Paris...:

\begin{tabular}{|l|l|}
\hline$[\ldots]$ on boit une soupe chinoise & {$[\ldots]$ toma-se uma sopa chinesa } \\
pékinoise & de Pequim \\
debout au comptoir & de pé, no balcão \\
ça pourrait être à New York & podia ser em New Iorque \\
mais c'est aux Lilas & mas é em Les Lilas, subúrbio de Paris \\
dans le 9-3 & departamento nove três \\
un garçon maigre et brun, l'air mécontent, & un garçon, magro e moreno, nada contente, \\
transporte des caisses & carrega pacotes \\
de Coca & de Coca-Cola \\
et la patronne & e a dona \\
(si c'est la patronne) & (se é que é a dona) \\
range les cannettes & coloca as latinhas \\
dans un grand frigidaire & num grande freezer \\
c'est moderne (le frigidaire) et ancien (la Soupe) & isso é moderno (o freezer) e antigo (a sopa) \\
c'est ici et maintenant & isso é aqui e agora \\
le présent & le présent \\
\hline
\end{tabular}

"Le présent": será realmente necessário e produtivo traduzir "le présent"? Ou não será mais interessante e proveitoso oferecer um outro presente ao(à) leitor(a): a oportunidade de refletir sobre a própria linguagem, sobre o quanto e como as línguas se relacionam umas com as outras, sobre como a tradução é bem mais complexa do que se imagina? Sabemos bem que a maioria das pessoas acha que traduzir é algo simples, que uma ferramenta de tradução automática é o suficiente, e, consequentemente, vê-se tanta tradução mal feita por aí e o trabalho tradutório tão desvalorizado. Por isso creio que a tarefa do tradutor não seja somente fazer traduções, mas promover a conscientização de que traduzir não é jogar um texto no Google Tradutor (o que parece óbvio, mas apenas para quem parou alguma vez para refletir sobre tradução); e, se o texto traduzido permitir que tais reflexões sejam sugeridas no seu próprio corpo (como esse de Kaplan, em que diversas culturas e línguas se entrelaçam), melhor ainda.

Segundo Jiry Levy (apud NECKEL, 2012, p. 15), “o tradutor ilusionista oculta-se atrás do original [...], com o objetivo de despertar neste [no leitor] a ilusão tradutória, ou seja, a ilusão de que lê o original". Embora eu tenha a intenção de (até certo ponto) contribuir para essa "ilusão" (de que o(a) leitor(a) está lendo um texto de Leslie), em alguns momentos me identifico muito mais com o método que Levy opõe ao ilusionismo, o anti- 
traduzida por Leslie por "nostalgie", que, por sua vez, dispensa tradução para o leitor brasileiro, mas abre seus olhos para as (des)semelhanças entre as línguas/culturas e para as transformações que o ato tradutório implica. Nada é "intraduzível” (e, possivelmente, até nem mesmo tudo...):

\begin{tabular}{|l|l|}
\hline dans les rues de la ville & nas ruas da cidade \\
à Fortaleza & em Fortaleza \\
il y a une fête, un défilé & tem uma festa, um desfile \\
et partout le slogan & e por todos os lados o slogan \\
Coca-Cola mata a sede & 'Coca-Cola mata a sede' \\
Coca-Cola tue la soif & Coca-Cola tue la soif \\
e a saudade & 'e a saudade' \\
et la nostalgie & et la nostalgie \\
\hline
\end{tabular}

Nota-se igualmente que, bem como no 'chuchu' de três exemplos atrás, para que se saiba o que já estava em português em Kaplan e eu não tenha que usar o itálico e inserir uma nota de rodapé a cada termo lusófono empregado por ela (que é o que normalmente se faz no meio editorial), opto por marcá-los com aspas simples, dado que as aspas duplas já são utilizadas em algumas citações e que os itálicos devem ser reservados para aquilo que permanece em francês ou em inglês na tradução; e mencionarei essa estratégia na "Nota do tradutor" (na futura e iminente edição do livro). ${ }^{15}$

Em outros trechos prefiro simplesmente não traduzir a língua francesa, por causa da sua semelhança com o português ("pulsion"/ "propulsion"/ "anonymat"), como nos versos a seguir, que contêm uma parte que Leslie coloca em inglês e tampouco traduz para o francês ("it's a wide world/ a hard world"); só que, logo em seguida, algo do inglês, que ela não traduz, eu traduzo ("how do you fit in it/ how do you live in it"), ${ }^{16}$ por acreditar que não temos tanto contato com essa língua quanto

15 Para que não reste dúvida, reforço que o livro foi lançado entre a submissão e a publicação deste artigo, mas que preferi manter aqui as citações e as menções às traduções dos poemas assim como se encontravam no momento em que submeti este ensaio à revista para ser avaliado.

16 Quanto a esses dois versos ("how do you fit in it/ how do you live in it"), que constituem uma dessas partes em que métrica e rima são evidentes em Leslie, inclusive soando como dois hemistíquios de um alexandrino cuja sílaba da cesura ("it") é a mesma do fim do verso ("it"), preocupo-me também, ao traduzi-los, com a semelhança entre eles, em que a única coisa que varia são os verbos, "fit" e "live", que formam igualmente uma aliteração com suas vogais tônicas, ii. Por isso opto por "caber" e "viver" na tradução ("para caber neste mundo/ para viver neste mundo"), única diferença entre os versos do dístico, ambos apresentando o mesmo número de sílabas e ee tônicos. Todavia, mais uma vez (bem como 
um francês o tem (a Inglaterra e a França, sendo vizinhas, não têm opção, relacionam-se desde sempre, por bem ou por mal...):

\begin{tabular}{|l|l|}
\hline $\begin{array}{l}\text { it's a wide world } \\
\text { a hard world }\end{array}$ & $\begin{array}{l}\text { it's a wide world } \\
\text { a hard world }\end{array}$ \\
l'enfer est vert & $\begin{array}{l}\text { 'enfer est vert } \\
\text { pulsion } \\
\text { propulsion } \\
\text { anonymat } \\
\text { propulsion } \\
\text { anonymat }\end{array}$ \\
$\begin{array}{l}\text { it's a wide wide world } \\
\text { how do you fit in it } \\
\text { how do you live in it }\end{array}$ & $\begin{array}{l}\text { it's a wide wide world } \\
\text { how do you fit in it } \\
\text { how do you live in it }\end{array}$ \\
$\begin{array}{l}\text { oui, vraiment } \\
\text { comment on fait }\end{array}$ & $\begin{array}{l}\text { pois é, realmente } \\
\text { como é que se faz } \\
\text { para caber neste mundo } \\
\text { para viver neste mundo }\end{array}$ \\
\hline
\end{tabular}

A estrofe que vem após a precedente ("here or there/ here and there/ anywhere/ else") continuará em inglês n'O inferno é verde, sem tradução, bem como figurava em L'Enfer est vert, talvez porque, em parte, trata-se de uma repetição de um verso anterior ("anywhere else"), que já havia sido traduzido por Leslie, e porque se pressupõe que "here" e "there", palavras de um vocabulário de nível básico da língua inglesa, seja compreensível para todos(as). É por essa mesma razão que não toco na estrofe seguinte ("équilibre/ déséquilibre/ équilibre"), mantenho-a em francês na tradução; e pouco me importa se o(a) leitor(a) lusófono(a) entender essas três palavras como substantivos ou verbos no imperativo, a ideia de (des) equilíbrio permanecerá; mas muito me importa que ele estranhe esses acentos agudos nos ee, que ele entre em contato e (se) interrogue (com) a língua/cultura estrangeira, e que se reconheça também nela, apesar das diferenças em comparação com a sua. E há ainda um excerto em que não me atenho a manter em francês apenas duas ou três palavras, mas me atrevo a deixar frases inteiras intocadas, igualmente com a intenção (e a

no exemplo do alexandrino "invisível" de páginas atrás), apesar de manter a regularidade nos meus dois versos, chego a quatorze sílabas poéticas; a não ser que se leiam os "para" com uma pronúncia mais informal ("pra”), chegando-se assim, de fato, ao somatório das doze sílabas poéticas de um alexandrino. 
esperança) de que a compreensão se efetue graças às similaridades entre as línguas em questão, e que o(a) leitor(a) se dê conta de que os mundos que o texto tenta aproximar uns dos outros, de fato, não são tão distantes assim:

\begin{tabular}{|c|c|}
\hline $\begin{array}{l}\text { la complexité est un élément } \\
\text { de la réponse } \\
\text { et de la façon de répondre } \\
\text { au monde } \\
\text { mais, quand je pense à ce philosophe } \\
\text { qui ne veut pas qu'on réduise } \\
\text { "un phénomène historique terrible et ambigu" } \\
\text { - pour lui, le colonialisme - } \\
\text { à "un crime contre l'humanité" } \\
\text { mais pour parler de l'éducation, } \\
\text { restons simple } \\
\text { "les casseurs ne réclament pas d'écoles, ils les } \\
\text { brûlent" } \\
\text { et, pour le chômage, } \\
\text { "on ne va pas en classe pour être embauché mais } \\
\text { pour être enseigné" } \\
\text { tout ça dans Le Figaro du } 15 \text { novembre } 2005 \text {, } \\
\text { ça donne - ce genre de propos - envie d'être à } \\
\text { son tour } \\
\text { extrêmement simpliste } \\
\text { et de répondre: berk }\end{array}$ & $\begin{array}{l}\text { a complexidade é um elemento } \\
\text { da resposta } \\
\text { e da maneira de se responder } \\
\text { ao mundo } \\
\text { mas, quando penso naquele filósofo } \\
\text { que não quer que a gente reduza } \\
\text { "un phénomène historique terrible et ambigu" } \\
\text { - para ele, o colonialismo - } \\
\text { a "un crime contre l'humanité" } \\
\text { mas, para falar da educação, } \\
\text { simplifiquemos } \\
\text { "esses arruaceiros não pedem, e sim queimam } \\
\text { escolas" } \\
\text { e, quanto ao desemprego, } \\
\text { "a pessoa não vai para a sala de aula para ser } \\
\text { empregada mas para ser ensinada" } \\
\text { tudo isso no Figaro do dia } 15 \text { de novembro de } 2005 \text {, } \\
\text { isso - discursos desse tipo - dão vontade de se } \\
\text { fazer também } \\
\text { de simplista ao extremo } \\
\text { e responder: imbecil }\end{array}$ \\
\hline
\end{tabular}

Mas se há de convir que, de fato, não traduzir duas frases e, logo em seguida, traduzir outras duas, pode deixar o(a) leitor(a) com a pulga atrás da orelha, com a dúvida se, "no Figaro do dia 15 de novembro de 2005", ${ }^{17}$ havia citações em francês e em português. Entretanto, como já avisei, aquilo que estava em português no original não aparecerá entre aspas duplas, e sim aspas simples. Além disso, espero apenas que quem vier a ler a tradução reconheça por alto o que se quer dizer com "un crime contre l'humanité", algo não muito complexo (apesar de que, como se lê no início do trecho, "a complexidade é um elemento/ da resposta/ e da maneira de se responder/ ao mundo"); em casos de maior complexidade,

17 A informação “2005”, reaproveito-a n'“As palavras”, lançando mão de algo da própria autora, só que em outro momento, acrescentando o dado nos versos em que se comentam as revoltas no subúrbio de Paris. 
como "les casseurs ne réclament pas d'écoles, ils les brûlent", traduzamos, "simplifiquemos". 18

O importante, na minha opinião, é que haja marcas estrangeiras o suficiente na tradução para que, a partir do contato com a língua portuguesa, as relações entre elas sejam investigadas, questionadas, experimentadas, vividas, assim como o texto nos leva a relacionar as diferentes culturas ali em convívio, em palavras. A aproximação desses mundos diversos dos quais se fala n'O inferno é verde deve se dar não somente no plano temático, mas também no linguístico. É necessário que se perceba que o que pode e deve aproximar uma cultura da outra, faz com que povos tão distantes se entendam e se reconheçam uns nos outros (como seres humanos) e se respeitem; é o diálogo, é a troca de palavras, não (apenas) a troca de mercadorias ou (muito menos) a troca de tapas.

Como diz Marília Garcia (2014, p. 103), "a tradução é uma troca entre duas línguas"; afirma ainda que Leslie Kaplan "diz que a tradução é um beijo entre duas línguas”. Marília o diz pensando no poema bilíngue (em francês e inglês) que traduz de Leslie e insere no seu próprio livro, $U m$ teste de resistores: "Translating is sexy" [Traduzir é sexy]. ${ }^{19}$ Também no caso d'“As palavras", ou melhor, "Les mots", de Kaplan, duas línguas estão trocando beijos explícitos, igualmente a inglesa e a francesa. E, em L'enfer est vert, é verdade que há instantes em que as trocas ocorrem entre duas línguas, como mais ao fim do poema; só que, ali, são entre a francesa e a portuguesa, e, agora que já conhecemos essa história de que "traduzir é sexy", como "um beijo entre duas línguas", não é à toa que ali seja citada uma canção de Aldir Blanc e João Bosco na qual se sonha com um beijo:

$18 \mathrm{O}$ último trecho é um dos que sofreu várias alterações até se chegar à versão final publicada, embora nenhuma dessas modificações comprometa as reflexões que faço aqui. 19 "Translating is sexy", de Leslie Kaplan, o original (em francês e inglês), pode ser lido na revista digital do coletivo remue.net (disponível em: <http://remue.net/spip. php?article2605>). 


\begin{tabular}{|l|l|}
\hline l'enfer est vert & l'enfer est vert \\
comme les rêves des boias frias & como les rêves, os sonhos \\
les gamelles froides & dos 'boias-frias', les gamelles froides \\
espantando a tristeza & para passar medo na tristesse \\
pour faire peur à la tristesse & 'espantando a tristeza \\
sonham com bife a cavalo, batata frita & sonham com bife a cavalo, batata frita' \\
ils rêvent d'un steak frites & ils rêvent d'un steak frites \\
e a sobremesa & 'e a sobremesa' \\
et pour le dessert & \\
é goiabada cascão com muito queijo & une 'goiabada' avec beaucoup de fromage \\
une goiabada avec beaucoup de fromage & 'é goiabada cascão com muito queijo \\
depois café, cigarro e um beijo & depois café, cigarro e um beijo' \\
de uma mulata chamada & d'une mulâtre qui s'appelle \\
Leonor ou Dagmar... & Léonore ou Dagmar... \\
et après le café une cigarette et un baiser & \\
d'une mulâtre qui s'appelle & 'de uma mulata chamada \\
Léonore ou Dagmar... & Leonor ou Dagmar...' \\
\hline
\end{tabular}

Mas, conforme o que vimos noutras páginas, essa história de beijo(s) de língua(s) se complexifica: o que antes, em "Translating is sexy”, era um casal, torna-se um ménage à trois, um troca-troca a três, três línguas se beijando n'O inferno. "Assim sendo", para me despedir como me despeço na "Nota do tradutor - tradução e promiscuidade" (presente, repito, no livro que está sendo produzido pela editora Luna Parque com as traduções aqui comentadas),

- para não falar que não falei em fidelidade - para ser

fiel

à sua promiscuidade [à promiscuidade dos versos de Leslie]

- ao trio de línguas que ali se entrelaçam -,

$[\ldots]$

optei por uma experiência trilíngue também ao traduzir,

[...]

com o desejo de que, dessarte, os novos leitores (lusófonos) de

possam gozar de prazeres tão promíscuos quanto os dos

[Leslie

[francófonos (já mais íntimos dela),

saborear as trocas entre três bocas - no mínimo: a de Leslie, a

[minha e a sua -

e degustar os beijos de três línguas - ao menos: francês, inglês

ainda que esses beijos possam não ser

[e português -,

tão doces assim.

Bises! Kisses! Beijos! 


\title{
LESLIE KAPLAN'S HELL IS GREEN AND “THE WORDS” TRANSLATED INTO PORTUGUESE (STILL UNPUBLISHED)
}

\begin{abstract}
Leslie Kaplan was born in New York in 1943, but was raised in France since her early childhood. She writes plays, novels, poems, theory and all of this especially in French. Few of her works can be found in Brazil and that certainly is one of the reasons which made me select and translate two of her long poems (still unpublished in our language, but not for long, thanks to Luna Parque, that will publish them very soon): $O$ inferno é verde (L'enfer est vert [Hell is green]) and "As palavras (escrever, literatura e sociedade)" ("Les mots (écrire, littérature et société)" [The Words: Writing, Literature and Society]). Kaplan's poetry brings to mind questions about the translation of poems that are very similar to prose (even if her free verse doesn't always seem so free) and reflections on how one can translate a text written in more than one language and which brings closer together cultures that seem very distant from one another, because the author's trip to Recife is the point of departure of L'Enfer est vert, which contains parts in French, in English and in Portuguese. Excerpts of the translation are analyzed in comparison to the original and the translator's choices are justified with the help of several writings on translation, including Leslie's own words: "translating is sexy".
\end{abstract}

Keywords: Leslie Kaplan; French Poetry; Translation.

\section{REFERÊNCIAS}

ALFERI, Pierre. Rumo à prosa. Trad. Masé Lemos e Paula Glenadel. ALEA, Rio de Janeiro, v. 15, n. 2, jul./dez. 2013, pp. 423-427.

ARROJO, Rosemary. Oficina de tradução: a teoria na prática. São Paulo: Ática, 1986.

BLANCHOT, Maurice. L'excès-l'usine ou l'infini morcelé. Libération, 24/o2/1987, p. 35.

BRITTO, Paulo Henriques. A tradução literária. Rio de Janeiro: Civilização Brasileira, 2012.

CAMPOS, Haroldo de. Metalinguagem \& outras metas: ensaios de teoria e crítica literária. 4. ed. São Paulo: Perspectiva, 2006.

ECO, Umberto. Dire presque la même chose: expériences de traduction. Trad. Myriem Bouzaher. Paris: Bernard Grasset, 2006.

FREITAS, Marcus Vinicius de. No verso dessa canoa (poesia, 1993-2005). Ilha de Vitória: Flor \& Cultura, 2005 .

GARCIA, Marília. Um teste de resistores. Rio de Janeiro: 7Letras, 2014.

GLEIZE, Jean-Marie. Post-poésie: un travail d'investigation-élucidation. Matraga, Rio de Janeiro, v. 17, n. 27, jul./dez. 2010, pp. 121-133.

GOLDSTEIN, Norma. Versos, sons, ritmos. 13. ed. São Paulo: Ática, 2002. 
JAKOBSON, Roman. On Linguistic Aspects of Translation. In: BROWER, R. A. (org.). On Translation. Harvard University Press, 1959, pp. 232-239.

JAKOBSON, Roman. Aspects Linguistiques de la Traduction. In: Essais de linguistique générale: 1. Les fondations du langage. Trad. Nicolas Ruwet. Paris: Les Éditions de Minuit, 2003, pp. 78-86.

JAKOBSON, Roman. Linguística e comunicação. 24. ed. Trad. Izidoro Blikstein e José Paulo Paes. São Paulo: Cultrix, 2007.

JOUSSERAND, Félix. Discussion entre Félix Jousserand et Catherine Peillon. La pensée de midi, n. 28, n. 2, 2009, pp. 178-184.

KAPLAN, Leslie. L'excès-l'usine ou l'infini morcelé. Libération, 24/o2/1987, p. 35.

KAPLAN, Leslie. Le psychanalyste. Paris: POL, 1999. [Depuis maintenant, 3].

KAPLAN, Leslie. O psicanalista. Trad. Rosa Freire d'Aguiar. São Paulo: Companhia das Letras, 2001.

KAPLAN, Leslie. L'enfer est vert. Publie.net, 2013[2006].

KAPLAN, Leslie. Les mots. Publie.net, 2013[2007].

KAPLAN, Leslie; POGGIOLI, Anna; MURILlO, Céline; TORTI-ALCAYAGA, Agathe; SYLVANISE, Frédéric. Dialogue avec Leslie Kaplan: passage de l'écriture romanesque à l'écriture théâtrale. Itinéraires, n. 2, 2014-2, 2015. Disponível em: <http:// itineraires. revues.org/2521>. Acesso em: 14 set. 2017.

KAPLAN, Leslie. O inferno é verde (seguido de As palavras). Trad. Zéfere. São Paulo: Luna Parque, 2018.

LEMOS, Masé. Poética(s) de ovni: alguns percursos teóricos da (pós) poesia moderna e contemporânea. O percevejo [on-line], v. 6, n. 2, jul./dez. 2014, pp. 128-150.

LEMOS, Masé. Qualidades para uma poesia sem qualidades. Aletria, Belo Horizonte, v. 27, n. 3, 2017, pp. 129-146.

NANCY, Jean-Luc. Fazer, a poesia. Trad. Letícia Della Giacoma de França, Janaina Ravagnoni e Mauricio Mendonça Cardozo. ALEA, Rio de Janeiro, v. 15, n. 2, jul./dez. 2013, pp. 414-422.

NECKEL, Filipe Mendes. Breve introdução ao pensamento tradutológico de Jiry Levy. Scientia Traductionis, n. 11, 2012, pp. 10-23.

OUSTINOFF, Michaël. Tradução: história, teorias e métodos. Trad. Marcos Marcionilo. São Paulo: Parábola Editorial, 2011.

RÓNAI, Paulo. Escola de tradutores. 7. ed. Rio de Janeiro: José Olympio, 2012. 
Remate de Males, Campinas-SP, v.38 n.2, pp. 726-762, jul./dez. 2018 - 755

TORTI-ALCAYAGA, Agathe. Techniques du saut: présentation de Leslie Kaplan. Itinéraires, 2014-2, 2015. Disponível em: <http:// itineraires.revues.org/2524>. Acesso em: 14 set. 2017.

VENUTI, Lawrence. The Translator's Invisibility: A History of Translation. Londres/Nova York: Routledge, 1995. 


\section{ANEXO}

\section{Trechos de "Les mots" / "As palavras" e L'Enfer est vert / O inferno é verde}

\begin{tabular}{|c|c|}
\hline Les mots & As palavras \\
\hline 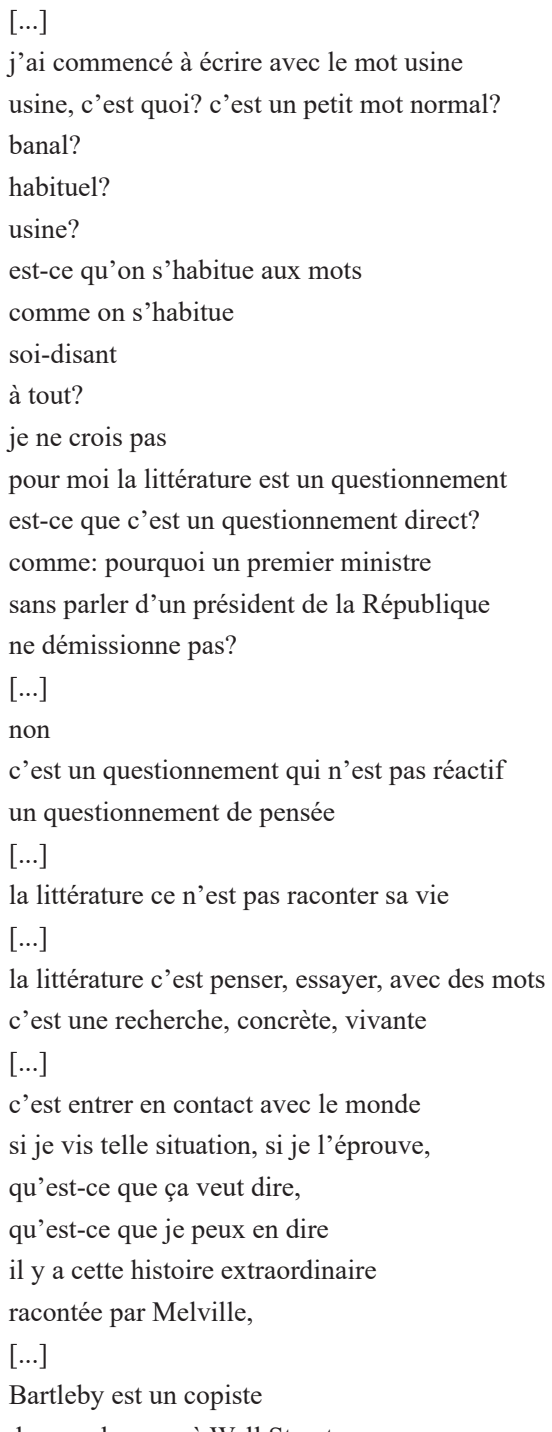 & $\begin{array}{l}\text { [...] } \\
\text { comecei a escrever com a palavra fábrica } \\
\text { fábrica é o quê? uma palavrinha normal? } \\
\text { banal? } \\
\text { comum? } \\
\text { fábrica? } \\
\text { será que a gente se acostuma com as palavras } \\
\text { como se acostuma } \\
\text { supostamente } \\
\text { com tudo? } \\
\text { acho que não } \\
\text { para mim a literatura é um questionamento } \\
\text { será que é um questionamento direto? } \\
\text { por exemplo: por que um primeiro ministro } \\
\text { para não falar num presidente da República } \\
\text { não renuncia? } \\
\text { [...] } \\
\text { não } \\
\text { este é um questionamento não reativo } \\
\text { um questionamento do pensamento } \\
\text { [...] } \\
\text { literatura não é contar a sua vida } \\
\text { [...] } \\
\text { literatura é pensar, experimentar, com palavras } \\
\text { é uma busca, concreta, viva } \\
\text { [...] } \\
\text { é entrar em contato com o mundo } \\
\text { se eu vivo algo, se eu passo por tal situação, } \\
\text { o que é que isso quer dizer, } \\
\text { o que é que eu posso dizer disso } \\
\text { tem aquela história extraordinária } \\
\text { contada por Melville, } \\
\text { [...] } \\
\text { Bartleby é um copista } \\
\end{array}$ \\
\hline
\end{tabular}




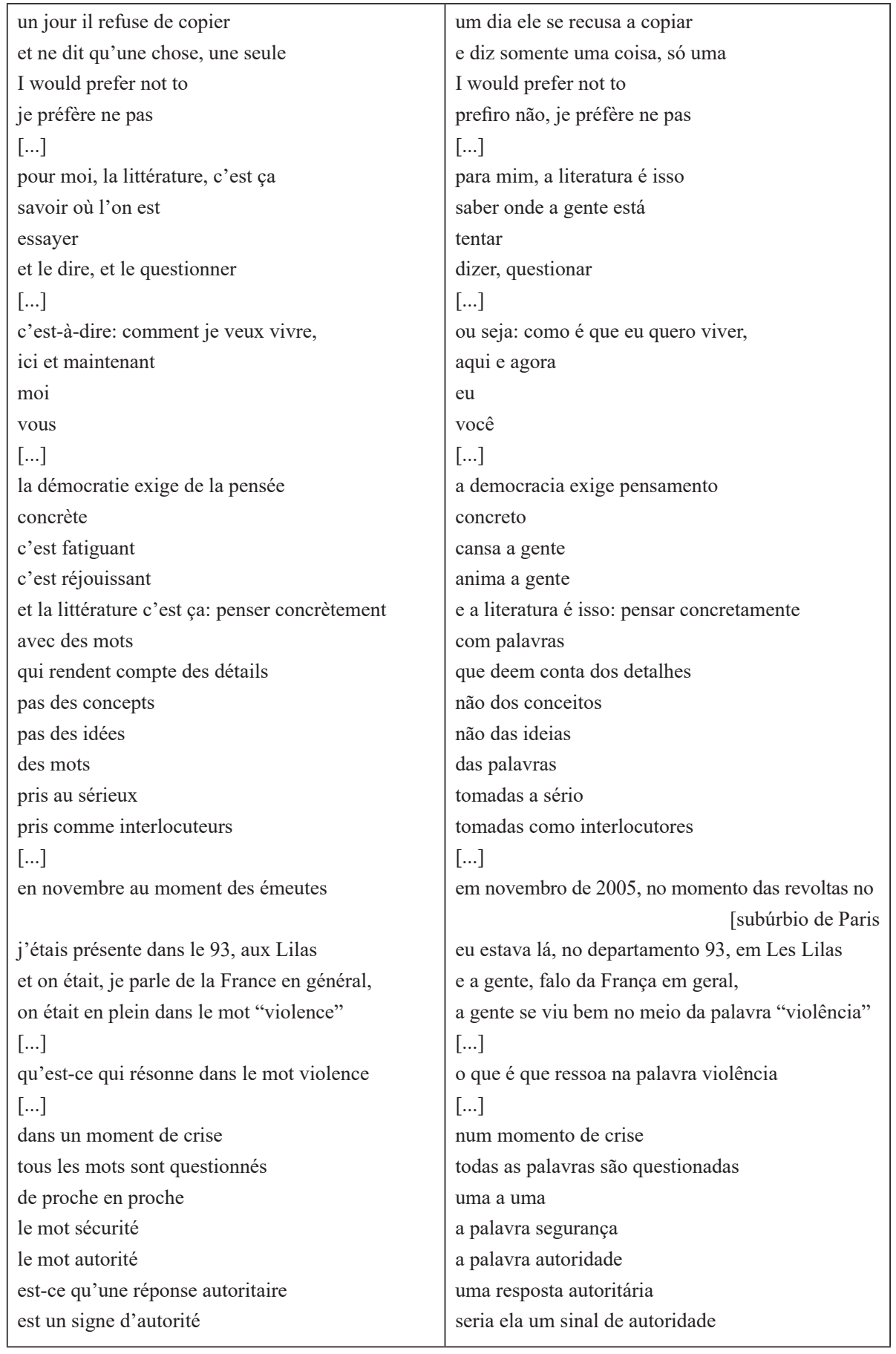




\begin{tabular}{|c|c|}
\hline $\begin{array}{l}\text { ou au contraire de manque d’autorité } \\
\text { réelle } \\
\text { d'autorité porteuse de sens } \\
\text { la littérature est une façon de penser } \\
\text { qui travaille les mots } \\
\text { qui se laisse travailler par eux } \\
{[\ldots]} \\
\text { et tente de faire entendre toujours à nouveau } \\
{[\ldots]}\end{array}$ & $\begin{array}{l}\text { ou, pelo contrário, de falta de autoridade } \\
\text { real } \\
\text { de autoridade portadora de sentido } \\
\text { a literatura é uma forma de pensar } \\
\text { que trabalha as palavras } \\
\text { que se deixa trabalhar por elas } \\
{[\ldots]} \\
\text { e tenta fazer com que sejam ouvidas sempre } \\
{[\ldots]}\end{array}$ \\
\hline & O inferno é verde \\
\hline $\begin{array}{l}\text { la première fois que je suis allée au Brésil } \\
{[\ldots . .]} \\
\text { j’ai vu un mur avec une inscription } \\
\text { un graffiti } \\
\text { o inferno é verde } \\
\text { l'enfer est vert } \\
\text { l'enfer est vert } \\
\text { comme le bloc bleu } \\
\text { du ciel } \\
\text { comme le rouge de la favela } \\
\text { [...] } \\
\text { comme les flamants roses } \\
\text { et les pumas tachetés } \\
\text { et les crocodiles marron } \\
\text { qui jouent dans le zoo de l'hôtel Tropical } \\
\text { à Manaus } \\
\text { où les clients payent par jour dix salaires mi- } \\
\text { nimum } \\
\text { (dix salaires mensuels) } \\
\text { et s'ennuient } \\
\text { et dorment } \\
\text { affalés } \\
\text { dans les grands fauteuils } \\
\text { [...] } \\
\text { l'enfer est vert } \\
\text { comme la terre qui s'effrite } \\
\text { les gens mangent des rats } \\
\text { et à dix kilomètres }\end{array}$ & $\begin{array}{l}\text { l'enfer est verde } \\
\text { como o azul maciço } \\
\text { do céu } \\
\text { como o vermelho da 'favela' } \\
{[\ldots . .]} \\
\text { como os flamingos rosa } \\
\text { e as onças-pintadas } \\
\text { e os jacarés marrons } \\
\text { que brincam no zoológico do Hotel Tropical } \\
\text { em Manaus } \\
\text { onde os hóspedes pagam uma diária de dez salários } \\
\text { [dénimos } \\
\text { e se entediam } \\
\text { e dormem } \\
\text { estatelados } \\
\text { em grandes poltronas } \\
\text { [...] } \\
\text { l'enfer est verde } \\
\text { como a terra que desaba } \\
\text { gente comendo rato } \\
\text { e a dez quilômetros de lá }\end{array}$ \\
\hline
\end{tabular}




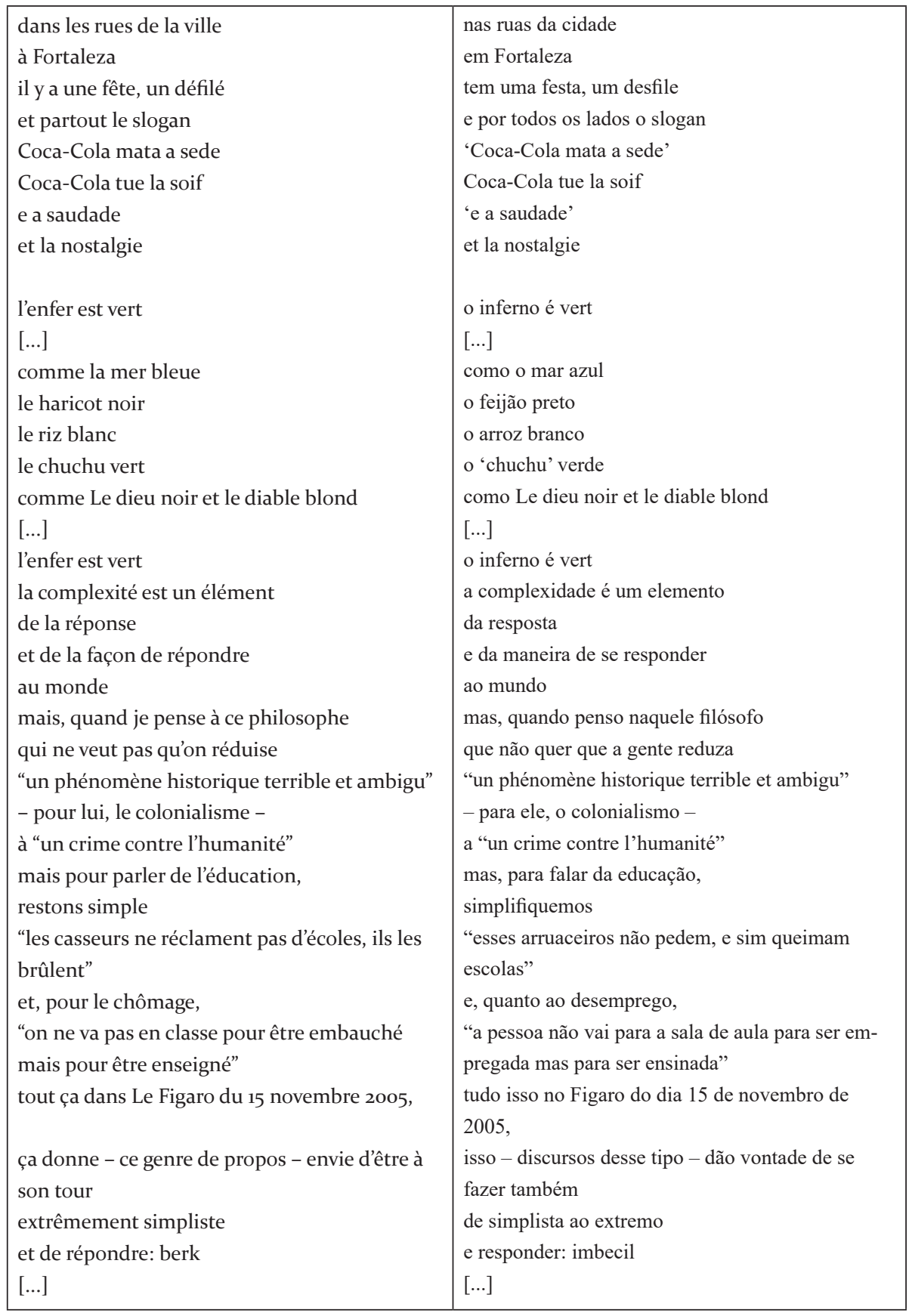




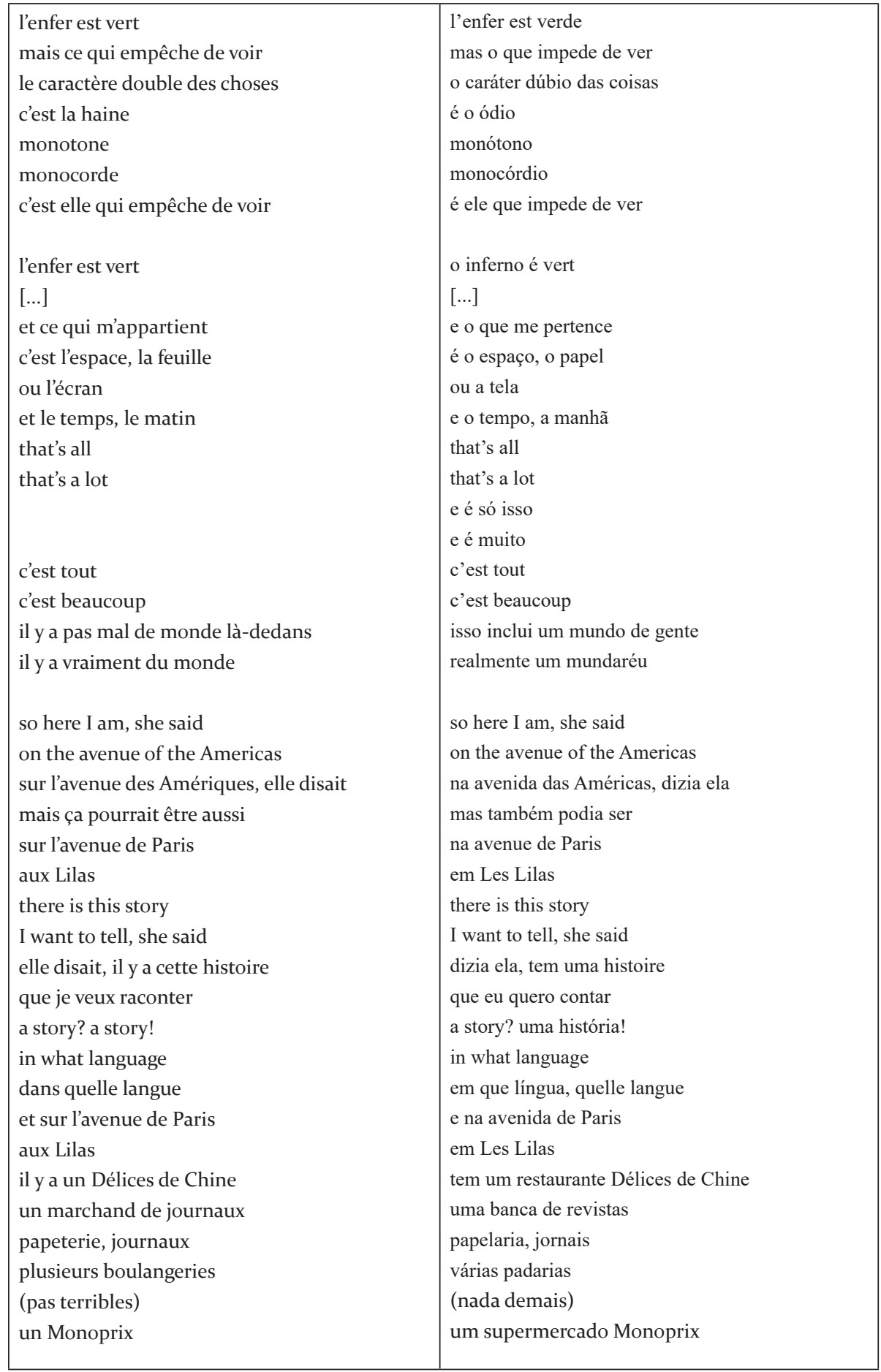


Remate de Males, Campinas-SP, v.38 n.2, pp. 726-762, jul./dez. 2018 - 761

\begin{tabular}{|c|c|}
\hline un magasin de blanc & uma loja de cama, mesa e banho \\
\hline un, deux, trois bureaux de tabac & um, dois, três pontos de venda de cigarros \\
\hline tout ça à la sortie du métro & tudo isso na saída do metrô \\
\hline et aussi une rôtisserie & e também tem carne assada \\
\hline (odeurs, grillé) & (cheiros, grelha) \\
\hline un marchand de légumes, des halles & um verdureiro, barracas de feira \\
\hline une lingerie & lingerie \\
\hline des jouets & brinquedos \\
\hline qu'est-ce qui fait que c'est & o que é que faz com que isso seja \\
\hline aux Lilas & Les Lilas \\
\hline et pas & e não \\
\hline à New York & Nova York \\
\hline or anywhere else & or anywhere else \\
\hline ou n'importe où ailleurs & ou qualquer outro lugar \\
\hline$[\ldots]$ & {$[\ldots]$} \\
\hline it's a wide world & it's a wide world \\
\hline a hard world & a hard world \\
\hline l'enfer est vert & l'enfer est vert \\
\hline pulsion & pulsion \\
\hline propulsion & propulsion \\
\hline anonymat & anonymat \\
\hline it's a wide world & it's a wide world \\
\hline how do you fit in it & how do you fit in it \\
\hline \multirow[t]{2}{*}{ how do you live in it } & how do you live in it \\
\hline & pois é, realmente \\
\hline oui, vraiment & como é que se faz \\
\hline \multirow[t]{2}{*}{ comment on fait } & para caber neste mundo \\
\hline & para viver neste mundo \\
\hline here or there & here or there \\
\hline here and there & here and there \\
\hline anywhere & anywhere \\
\hline else & else \\
\hline équilibre & équilibre \\
\hline déséquilibre & déséquilibre \\
\hline équilibre & équilibre \\
\hline
\end{tabular}




\begin{tabular}{|c|c|}
\hline $\begin{array}{l}\text { l'enfer est vert } \\
\text { et on boit une soupe chinoise } \\
\text { pékinoise } \\
\text { debout au comptoir } \\
\text { ça pourrait être à New York } \\
\text { mais c'est aux Lilas } \\
\text { dans le 9-3 } \\
\text { un garçon maigre et brun, l'air mécontent, } \\
\text { transporte des caisses } \\
\text { de Coca } \\
\text { et la patronne } \\
\text { (si c'est la patronne) } \\
\text { range les cannettes } \\
\text { dans un grand frigidaire } \\
\text { c'est moderne (le frigidaire) et ancien (la soupe) } \\
\text { c'est ici et maintenant } \\
\text { le présent }\end{array}$ & $\begin{array}{l}\text { l'enfer est vert } \\
\text { e toma-se uma sopa chinesa } \\
\text { de Pequim } \\
\text { de pé, no balcão } \\
\text { podia ser em New Iorque } \\
\text { mas é em Les Lilas, subúrbio de Paris } \\
\text { departamento nove três } \\
\text { un garçon, magro e moreno, nada contente, } \\
\text { carrega pacotes } \\
\text { de Coca-Cola } \\
\text { e a dona } \\
\text { (se é que é a dona) } \\
\text { coloca as latinhas } \\
\text { num grande freezer } \\
\text { isso é moderno (o freezer) e antigo (a sopa) } \\
\text { isso é aqui e agora } \\
\text { le présent }\end{array}$ \\
\hline $\begin{array}{l}\text { l'enfer est vert } \\
{[\ldots . .]} \\
\text { l'enfer est vert } \\
\text { comme les rêves des boias frias } \\
\text { les gamelles froides } \\
\text { espantando a tristeza } \\
\text { pour faire peur à la tristesse } \\
\text { sonham com bife a cavalo, batata frita } \\
\text { ils rêvent d'un steak frites } \\
\text { e a sobremesa } \\
\text { et pour le dessert } \\
\text { é goiabada cascão com muito queijo } \\
\text { une goiabada avec beaucoup de fromage } \\
\text { depois café, cigarro e um beijo } \\
\text { de uma mulata chamada } \\
\text { Leonor ou Dagmar... } \\
\text { et après le café une cigarette et un baiser } \\
\text { d'une mulâtre qui s'appelle } \\
\text { Léonore ou Dagmar... } \\
\text { [...] }\end{array}$ & $\begin{array}{l}\text { o inferno é verde } \\
{[\ldots . .]} \\
\text { l'enfer est vert } \\
\text { como les rêves, os sonhos } \\
\text { dos 'boias-frias', les gamelles froides } \\
\text { para passar medo na tristesse } \\
\text { 'espantando a tristeza } \\
\text { sonham com bife a cavalo, batata frita' } \\
\text { ils rêvent d'un steak frites } \\
\text { 'e a sobremesa' } \\
\text { une 'goiabada' avec beaucoup de fromage } \\
\text { 'é goiabada cascão com muito queijo } \\
\text { depois café, cigarro e um beijo' } \\
\text { d'une mulâtre qui s'appelle } \\
\text { Léonore ou Dagmar... } \\
\text { 'de uma mulata chamada } \\
\text { Leonor ou Dagmar...' } \\
\text { [...] }\end{array}$ \\
\hline
\end{tabular}

